UDK 614: 614.3

\title{
HYGIENIC ASSESSMENT OF THE CONTENTS CHEMICAL CONTAMINANTS IN FOOD AND THE RISK ASSESSMENT OF INFLUENCE OF FOOD PRODUCTS ON THE HEALTH OF THE POPULATION OF THE ORENBURG REGION
}

\author{
L.M. Tulina², N.E. Vyaltsina', T.M. Makarova', E.G. Plotnikova', \\ A.A. Neplokhov' ${ }^{2}$ G.V. Sadchikova ${ }^{2}$ \\ ${ }^{1}$ Orenburg Region Department of the Federal Service on Consumer Rights \\ Protection and Human Well-Being Surveillance, Russia, \\ ${ }^{2}$ Federal Budget Healthcare Institution \\ "Orenburg Region Center for Hygiene and Epidemiology", \\ 48, Kirova St., , Russia
}

\begin{abstract}
The hygienic assessment of the maintenance of contaminants in food and the risk assessment of influence of food products on health of the population of the Orenburg Region has been carried out. Groups of products making the greatest contribution to the exposition to the studied chemicals and to the development of cancerogenic and non-cancerogenic risk for the population health have been defined. The received results are used for the improvement of the state sanitary and epidemiologic supervision and taking administrative decisions. Key words: food products, chemical contaminants, risk for the population health.
\end{abstract}

In accordance with the Doctrine on food products safety of the Russian Federation adopted by the Presidential Decree \#120 dated 30.01.2010, one of the main tasks is to secure food products safety at all the stages of its production and storage, transportation, processing and realization [1]. Food products safety is determined by their correspondence with the requirements of sanitation legislation, technical regulations on sanitation-chemical, microbiological and organoleptical constituents [2].

On the basis of methodological approaches recommended by the Federal Agency in the Sphere of consumer rights protection and human well-being $[3,5,6$,] there has been conducted hygienic assessment of the presence of chemical contaminants in food products and their impact on population health in Orenburg region as for the data of regional information fund of Sanitation-Hygienic Regulations.

(c) Tulina L. M., Vyaltsina N. E., Makarova T. M., Plotnikova E. G., Neplokhov A. A., Sadchikova G. V., 2014

Tulina Larisa Mikhailovna - candidate of medical sciences, head of social-hygienic monitoring and risk assessment department (e-mail: fguz2005@mail.ru; tel. 8 (3532) 77-28-77).

Vyaltsina Natalya Efimovna - director (e-mail: oren-rpn@esoo.ru; tel. 8 (3532) 33-37-98). 34).

Makarova Tatiana Mikhailovna- candidate of medical science, deputy director (e-mail: oren-rpn@esoo.ru; tel. 8 (3532) 33-35-

Plotnikova Elena Georgievna- head of the social-hygienic monitoring department (e-mail: oren-rpn@esoo.ru; tel. 8 (3532) 7080-70).

Neplokhov Andrey Aleksandrovich - candidate of medical science, head of risk assessment department (e-mail: fguz2005@mail.ru; tel.8 (3532) 77-90-62).

Sadchikova Galina Vladimirovna - doctor of social-hygienic monitoring and risk assessment department (e-mail:

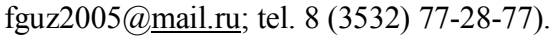


Within 2012, in Orenburg region about 3,700 samples of food products were selected and studied. Those are the products consumed by the population and they were studied to check the presence of heavy metals, nitrates, pesticides, caesium-137, strontium-90 [4].

Both, local and imported food products as well as the products grown at agricultural fields and gardens of Orenburg region were assessed.

All the selected food products samples were studied both raw (fruit, vegetables, berries) and after culinary treatment (potatoes, meat, fish, milk, butter, bakery products and noodle products).

At the first stage of the study there was conducted the analysis of chemical contaminants contained in the main groups of products which showed that the excess of the admissible level of the lead (1.5 AL) is registered in milk products of Kvarkenskiy district and in flour of local production of Aleksandrovskiy district.

At the level of 1.0 AL the content of aflatoxin in dairy products was registered in Adamovskiy, Akbulakskiy, Kvarkenskiy, Novoorskiy and Perevolotskiy districts, dichlorodiphenyl-trichloroethane in grain products (flour and grains) was registered in Gai and Sorochinskiy district, in confectionary of Kvarkenskiy district, cadmium in sunflower grains of Novotroitsk and in milk and dairy products of Perevolotsk and Perevolotsk district.

Annual average concentration of chemical elements in all the groups of the studied products didn't exceed the admissible level (table 1).

The content of nitrates in vegetables in 2012 on average in Orenburg region also didn't exceed the admissible hygienic levels (in shares of AL): watermelons- 0.43 , melons -0.72 , cabbage (early) - 0.22, cabbage (late) - 0.26, carrots (early) - 0.22, carrots (late) - 0.47, beetroots -0.51 , tomatoes -0.32 , cucumbers (ordinary) -0.5 , cucumbers (greenhouse) -0.4 , onions (bulb) -0.54 , potatoes -0.35 .

The second stage of the study implied the assessment of the contaminants exposition of food products while consumed by the population and detection of the main product groups contributing to the summary exposition to the greatest extent.

Further on, on the basis of exposition calculation there was performed the calculation of the contribution to the overall value of the exposition the results of which are represented in table 2.

While ranging the studied groups of food products it is determined that the greatest contribution to the lead exposition (57\% of the general contribution) and cadmium (59\%) are made by bakery products, vegetables and gourds, meat and meat products; to the arsenic exposition (83.6\%) - bakery products, vegetables, gourds, fish and fish products; to the 
quicksilver exposition (74\%) - fish, bakery products, vegetables and gourds; to the exposition of bakery products and gourds - $(90.4 \%)$, meat and meat products; to the exposition of dichlorodiphenyl-trichloroethane $(87.6 \%)$ - meat and meat products, bakery products, vegetables and gourds; to the exposition of aflatoxin (93.3\%) - bakery products, vegetables and gourds, potatoes.

Table 1

Average annual concentration of chemical elements in the main groups of production in Orenburg Region over 2012 (in shares of $\mathbf{A L}$ )

\begin{tabular}{|l|c|c|c|c|c|c|c|c|}
\hline \multirow{2}{*}{ Chemical element } & \multicolumn{9}{|c|}{ Product group } \\
\cline { 2 - 9 } & $\begin{array}{c}\text { Meat } \\
\text { and meat } \\
\text { products }\end{array}$ & Milk & $\begin{array}{c}\text { Bakery } \\
\text { products }\end{array}$ & Vegetables & Drinks & Fish & $\begin{array}{c}\text { Sugar and } \\
\text { confectionary } \\
\text { products }\end{array}$ & Oil and butter \\
\hline Quicksilver & 0,025 & 0,15 & 0,025 & $0,02-0,04$ & 0,053 & 0,5 & 0,043 & 0,024 \\
\hline Cadmium & 0,081 & 0,14 & 0,073 & $0,1-0,15$ & 0,2 & 0,042 & 0,061 & 0,1 \\
\hline Lead & 0,08 & 0,28 & 0,07 & $0,06-0,07$ & 0,04 & 0,11 & 0,08 & 0,3 \\
\hline Arsenic & 0,09 & 0,25 & 0,11 & $0,03-0,06$ & 0,07 & 0,01 & 0,01 & 0,14 \\
\hline Hexachlorane & 0,14 & 0,13 & 0,02 & $0,003-0,005$ & & 0,03 & 0,02 & 0,009 \\
\hline $\begin{array}{l}\text { Dichloro- } \\
\text { diphenyl- } \\
\text { trichloroethane }\end{array}$ & 0,15 & 0,12 & 0,23 & $0,01-0,03$ & & 0,03 & 0,52 & 0,01 \\
\hline Aflatoxin & & 0,52 & 0,13 & & & & 0,13 & 0,07 \\
\hline
\end{tabular}

\section{Ranging the food products according to their contribution to the general values of expostion*}

\begin{tabular}{|l|c|c|c|c|c|c|c|}
\hline \multirow{3}{*}{ Group of products } & \multicolumn{9}{|c|}{ Lead } & Cadmium & Arsenic & Hexachlorane & Aflatoxin & Quicksilver & $\begin{array}{c}\text { Dichloro- } \\
\text { dyphenyl- } \\
\text { trichloroeth } \\
\text { ane }\end{array}$ \\
\cline { 2 - 8 } & $\begin{array}{c}\% \\
\text { (range) }\end{array}$ & $\begin{array}{c}\% \\
\text { (range) }\end{array}$ & $\begin{array}{c}\% \\
\text { (range) }\end{array}$ & $\begin{array}{c}\% \\
\text { (range) }\end{array}$ & $\begin{array}{c}\% \\
\text { (range) }\end{array}$ & $\begin{array}{c}\% \\
\text { (range) }\end{array}$ & $\begin{array}{c}\% \\
\text { (range) }\end{array}$ \\
\hline Bakery products & $23,3(1)$ & $21,9(1)$ & $53,6(1)$ & $47,7(1)$ & $38,0(1)$ & $19,0(2)$ & $26,4(2)$ \\
\hline Meat and meat products & $16,0(3)$ & $17,7(3)$ & 10,3 & $38,5(2)$ & & 7,7 & $53,1(1)$ \\
\hline Milk and dairy products & 2,9 & 4,5 & 3,3 & 1,6 & 1,3 & 3,9 & 1,4 \\
\hline Vegetables and gourds & $17,5(2)$ & $19,3(2)$ & $18,3(2)$ & $4,2(3)$ & $33,4(2)$ & $16,7(3)$ & $8,1(3)$ \\
\hline Potatoes & 10,8 & 12,7 & 9,1 & 2,8 & $21,9(3)$ & 5,5 & 3,8 \\
\hline Berries & 14,9 & 11,3 & 8,1 & 2,5 & & 4,9 & 3,4 \\
\hline Fish and fish products & 6,1 & 3,4 & $11,7(3)$ & 0,7 & & $38,3(1)$ & 1,0 \\
\hline Oil and other fats & 1,5 & 2,3 & 1,7 & 0,5 & 1,4 & 1,0 & 0,7 \\
\hline Sugar and confectionary & 6,8 & 6,9 & 5,0 & 1,5 & 4,0 & 3,0 & 2,1 \\
\hline
\end{tabular}

F o ot n ot e: * the first three ranges are showcased.

Thus, the greatest contribution into the exposition by the studied chemical elements on the territory of Orenburg region is made by the following product groups:

1) bakery products (up to $54 \%$ on arsenic; up to $48 \%$ on hexachlorane; up to $38 \%$ on aflatoxin); 
2) vegetables and gourds (33\% on aflatoxin);

3) meat and meat products (53\% on dichloro-diphenyl-trichloroethane; 38,5\% hexachlorane);

4) fish and fish products (38\% on quicksilver);

5) potatoes (up to $22 \%$ on aflatoxin).

At the next stage there was conducted the calculation of the hazard quotients from the presence of lead, cadmium, arsenic, quicksilver, pesticides (hexachlorane, dichloro-diphenyltrichloroethane) and aflatoxin in all the products included into the study (table 3 ).

Table 3

\section{Exposition and indexes of the threat of non-carcirogenic risks development from the studied chemical elements in food products}

\begin{tabular}{|l|l|c|c|}
\hline \multirow{2}{*}{ Chemical element } & \multicolumn{1}{|c|}{ Indicator } & $\begin{array}{c}\text { Assessed exposition } \\
(\mathrm{mg} / \mathrm{kg} / \mathrm{week})\end{array}$ & $\begin{array}{c}\text { Hazard quotient } \\
(H Q)\end{array}$ \\
\hline \multirow{2}{*}{ Lead } & Median line & 0.00034 & 0.014 \\
\cline { 2 - 4 } & 90th percentile & 0.019 & 0.765 \\
\hline \multirow{2}{*}{ Cadmium } & Median line & 0.00009 & 0.012 \\
\cline { 2 - 4 } & 90th percentile & 0.0014 & 0.194 \\
\hline \multirow{2}{*}{ Arsenic } & Median line & 0.00031 & 0.02 \\
\cline { 2 - 4 } & 90th percentile & 0.006 & 0.39 \\
\hline \multirow{2}{*}{ Quicksilver } & Median line & 0.000007 & 0.0014 \\
\cline { 2 - 4 } & 90th percentile & 0.0005 & 0.094 \\
\hline \multirow{2}{*}{ Hexachlorane } & Median line & 0.00007 & 0.007 \\
\cline { 2 - 4 } & 90 th percentile & 0.003 & 0.624 \\
\hline Dichloro-dyphenyl- & Median line & 0.0002 & 0.04 \\
\cline { 2 - 4 } trichloroethane & 90 th percentile & 0.002 & 0.452 \\
\hline \multirow{2}{*}{ Aflatoxin } & Median line & 0.00009 & 0.261 \\
\cline { 2 - 4 } & 90 th percentile & 0.0002 & 0.673 \\
\hline \multirow{2}{*}{ Nitrates } & Median line & 6.716 & 0.60 \\
\cline { 2 - 4 } & 90 th percentile & 15.092 & $\mathbf{1 . 3 4}$ \\
\hline \multirow{2}{*}{ IN TOTAL } & Median line & $\mathbf{6 . 7 2}$ & $\mathbf{H I = 4 , 5 3}$ \\
\cline { 2 - 4 } & $\mathbf{9 0}$ th percent & $\mathbf{1 5 , 1 2}$ & \\
\hline
\end{tabular}

The overall hazard quotient for the conditions of the simultaneous getting of several chemical elements per orally with food products on the whole for the population of Orenburg region made 0.96 on the median line and 4.53 on the 90th percentile which is higher than the level of non-carcinogenic risk created by drinking water on the territory of Orenburg region (0.76). The highest danger indexes are obtained from the impact of nitrates on food products 1.3 on 90th percentile. This level of the nitrate presence in food products requires a stricter control over its contents in the group of products with the greatest contribution to the exposition and it also requires conducting a deeper and more thorough assessment of the exposition on the basis of the data of individual population diet.

The assessment of non-carcinogenic risk with account of the overall calculated total danger indexes showed that the greatest contribution into the risk of non-oncological diseases 
from consumption of food products on the territory of Orenburg region are made by nitrates (29.5\%), lead (16.9\%), aflatoxin (14.8\%) and hexachlorane (13.8\%) (figure 1).

The annual average content of nitrates in vegetables made $55.2 \mathrm{mg} / \mathrm{kg}$ on the median line and $227.0 \mathrm{mg} / \mathrm{kg}$ - on the 90th percentile which corresponds with the average Exposition - 0.957 $\mathrm{mg} / \mathrm{kg} / 24$ hours on the median line and $2.150 \mathrm{mg} / \mathrm{kg} / 24$ hours on the 90 th percentile for the average adult person (weighing $70 \mathrm{~kg}$ ).

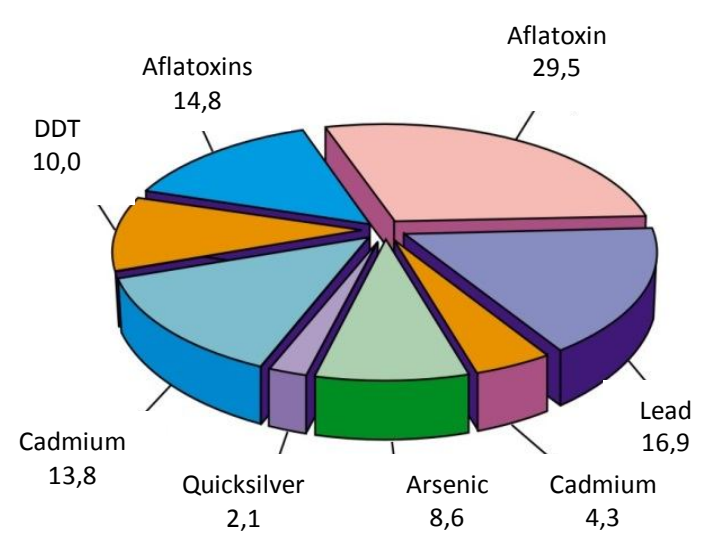

Figure 1. The structure of the summary non-carcinogenic risk (\%) trom consumption of food products on the territory of Orenburg region in 2012

The value of the danger index from nitrate impact on the median line is 0.6. Accordingly, the deeper assessment of the exposition is not required. The danger index on the 90th percentile is 1.34 which is a bit higher than the admissible level of 1.0.

The biggest contribution to the total value of exposition by nitrates $(90 \%)$ in Orenburg region in 2014 was made by beetroot $-28.3 \%$, potatoes $-20.4 \%$, greenhouse cucumbers $-9.8 \%$ and early cabbage $-9.5 \%$ (figure 2 ).

While analyzing total danger indexes for substances impacting on the same organs, the highest values of hazard indext (HI) were established for the group of substances influencing on the hormonal system (2.52) (table 4).

The main contribution on the influencing on the hormonal system is made, in the first term, by lead (30.7\%) and hexachlorane $(24.7 \%)$.

The second place on the amount of HI is given to the central nervous system (1.87), potential reason for disorder of which is, mainly, lead (41.2 \%) and hexachlorane (33.2\%).

The third place on the amount of $\mathrm{HI}$ is given to nitrates (77.5\%) impacting the cardiovascular system. Toxic impact on the blood (met $\mathrm{Hb}$ generation) $\mathrm{HI}=1.34$ is also conditioned by the impact of nitrates (100\%). 


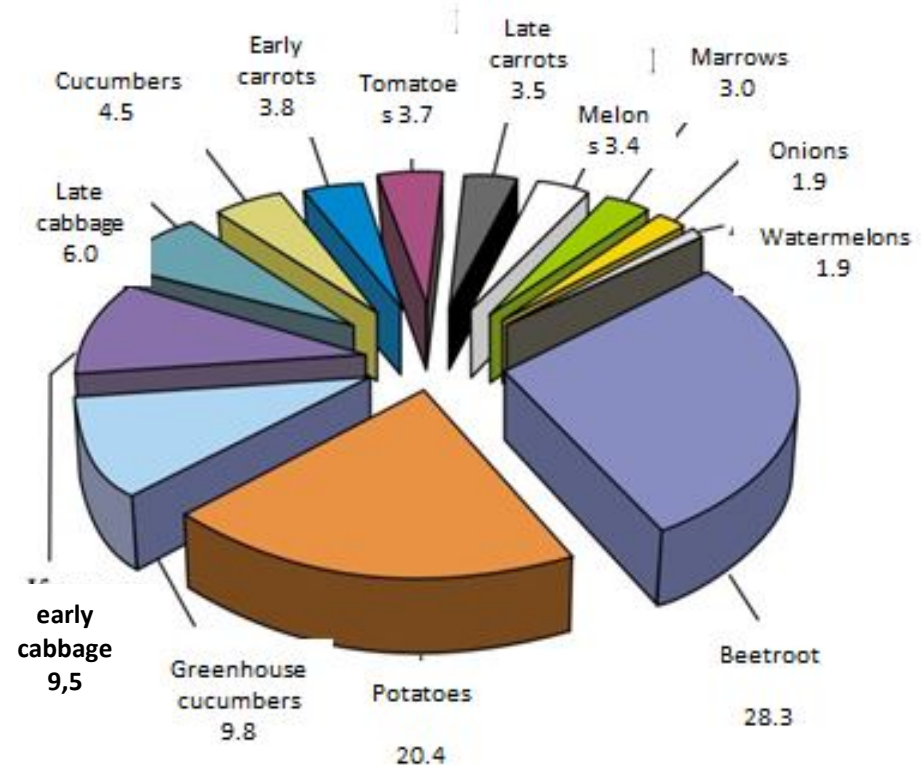

Figure 2. Ranging vegetable production in Orenburg region on contribution (\%) into the total value of nitrate exposition in 2012

Table 4

Total indexes of the danger indexes of non-carcinogenic effects under chronical impact of chemical substances in food products on separate organs and systems

\begin{tabular}{|l|c|l|}
\hline \multirow{2}{*}{\multicolumn{1}{|c|}{ Impacted organs and systems }} & \multicolumn{2}{|c|}{ Total hazard index $(H I)$} \\
\cline { 2 - 3 } & Median line & \\
\hline Hormonal system & 0.09 & Hormonal system \\
\hline Central nervous system & 0.04 & Central nervous system \\
\hline Cardiovascular system & 0.62 & Cardiovascular system \\
\hline Reproductive system & 0.02 & Reproductive system \\
\hline Blood & 0.6 & Blood \\
\hline Nervous system & 0.03 & Nervous system \\
\hline Immune system & 0.03 & Immune system \\
\hline Lever & 0.04 & Lever \\
\hline Kidneys & 0.02 & Kidneys \\
\hline Development & 0.02 & Development \\
\hline Gastrointestinal tract & 0.02 & Gastrointestinal tract \\
\hline
\end{tabular}

The risk of development of carcinogenic effects from consuming food products by the population of Orenburg region

\begin{tabular}{|l|c|c|c|c|l|c|c|}
\hline \multirow{2}{*}{ Carcinogens } & \multirow{2}{*}{$\mathrm{SF}_{\mathrm{o}}$} & \multicolumn{2}{|c|}{ Assessed exposition } & \multicolumn{2}{c|}{$\begin{array}{c}\text { Individual risk } \\
\text { (probability) }\end{array}$} & \multicolumn{2}{c|}{$\begin{array}{c}\text { Population risk (number } \\
\text { of cases) }\end{array}$} \\
\cline { 3 - 8 } & & $\begin{array}{c}\text { Median } \\
\text { line }\end{array}$ & $\begin{array}{c}90^{\text {th }} \\
\text { percentile }\end{array}$ & $\begin{array}{c}\text { Median } \\
\text { line }\end{array}$ & & & Median line \\
\hline Cadmium & 0.38 & $1.22 \mathrm{E}-05$ & 0.00019 & $4.64 \mathrm{E}-06$ & Cadmium & 0.38 & $1.22 \mathrm{E}-05$ \\
\hline Lead & 0.047 & $4.87 \mathrm{E}-05$ & 0.0027 & $2.29 \mathrm{E}-06$ & Lead & 0.047 & $4.87 \mathrm{E}-05$ \\
\hline Arsenic & 1.5 & $4.40 \mathrm{E}-05$ & 0.00083 & $6.61 \mathrm{E}-05$ & Arsenic & 1.5 & $4.40 \mathrm{E}-05$ \\
\hline Total & & $1.05 \mathrm{E}-04$ & 0.0038 & $7.30 \mathrm{E}-05$ & Total & & $1.05 \mathrm{E}-04$ \\
\hline
\end{tabular}

With account of the estimated doses on the population at the next stage there was conducted the calculation of carcinogenic risks from the impact of lead, cadmium and arsenic detected in the food products. The quantitative characteristics of individual risk of cancer 
development was estimated for the average life expectancy (70 years) for an adult person (weighing $70 \mathrm{~kg}$ ) and population carcinogenic risk in the form of additional (to the background level of morbidity) tumours among the studied population (Orenburg region on the whole).

On the whole, for all the population of the region the risk of carcinogenic effects from consuming food products is at the level which is higher than established by the international (1.0E-05) and Russian (1.0E-04) indicators (table 5).

Total carcinogenic risk on the median line corresponds with the upper level of the admissible risk (7.3E-05) and on the 90th percentile it makes 1.45E-03 and is non-admissible for the population in general. Calculated levels of individual carcinogenic risk at peroral intervention of arsenic (1.25E-03) and lead (1.28E-04) with food products are all non-admissible for the population. The greatest contribution $-86.1 \%$ into the total carcinogenic risk is made by arsenic, the second place is given to lead $-8.8 \%$.

Population carcinogenic risk (additional number of cancer cases for 70 years) from the impact of 3 carcinogens made 2,914.4 cases for all the population of Orenburg region (14.4 cases for 10 thousand people) including 2,532 cases from arsenic impact (12.5 cases for 10 thousand of people), 260 cases from lead impact (1.3 cases for 10 thousand people) and 149.5 cases from cadmium impact ( 0.7 cases for 10 thousand people).

In the present study the calculation of carcinogenic risk from consuming aflatoxin with food products and pesticides (dichloro-diphenyl-trichloroethane, hexachlorane) was not conducted because of the absence of the potential of those bounds in the Guidance on the assessment of risk factor.

The obtained results of the hygienic assessment of the presence of chemical contaminants in food products and assessment of the risk of food products impact on population health are used to improve the state sanitation and epidemiologic control in respect of the business units and their production control over food products and food raw materials. There has also been made plans correction in laboratory control in order to increase the volume of laboratory researches in respect of groups of food products and food raw materials making the greatest contribution into the exposition by chemical contaminants and into the levels of carcinogenic and non-carcinogenic risk. Within the framework of the information cooperation agreement the obtained results of hygienic assessment are offered to the office of Rospotrebnadzor in Orenburg region. Informing this Agency is performed on the constant basis about all the cases of excess of the admissible concentration of chemical substances in agricultural products in order to take the relevant managerial decisions. 


\section{Conclusion:}

1. Annual average concentrations of heavy metals (quicksilver, cadmium, lead, arsenic), pesticides (dichloro-diphenyl-trichloroethane, hexachlorane), aflatoxin and nitrates in vegetation products did not exceed the established hygienic standards. The excesses of annual average concentrations are registered with lead (1.5 AL) in dairy products of Kvarkenskiy district and the content of dichloro-diphenyl-trichloroethane $(1.25 \mathrm{AL})$ in the flour of local production of Aleksandrovskiy district. The content of strontium-90 and cesium-137 in all the groups of products did not exceed the established hygienic limits.

2. On the territory of Orenburg region the greatest contribution into the exposition by heavy metals - lead, cadmium, arsenic - is made by bakery products, quicksilver - by fish and fish products, aflatoxin - vegetables, gourds and potatoes, pesticides - meat and meat products, bakery products.

3. Total non-carcinogenic risk from the impact of chemical bounds of food products for population health in Orenburg region made 0.96 on the median line and 4.53 on the 90th percentile which is 1.3 times and 6 times higher than the total non-carcinogenic risk from the impact of drinking water (0.76). With this, the danger indexes exceeding the admissible level $(\mathrm{HI}>1)$ established for nitrates of food products -1.3 .

4. The biggest contribution into the non-oncological diseases risks from consuming food products on the territory of Orenburg region is made by nitrates $(29.5 \%)$, lead (16.9\%), aflatoxin (14.8\%) and hexachlorane (13.8\%).

5. The highest total values of danger indexes are estimated for the group of substances influencing on the hormonal system (2.52), central nervous system (1.87), cardiovascular system (1.48), reproductive system (1.48), blood (1.34) and nervous system (1.15).

6. Total carcinogenic risk from consuming food products at the level of median made 7.3E-05 and corresponds with the upper level of the admissible risk, and on the 90th percentile $1.45 \mathrm{E}-03$ - which is non-admissible for the population on the whole. The greatest contribution into the total carcinogenic risk is made by arsenic $(86.1 \%)$ and then lead $(8.8 \%)$.

7. The population carcinogenic risk from the impact of three carcinogens made 2,914.4 cases for all the population of Orenburg region, including 2,532 cases from the impact of arsenic, 260 cases from the impact of lead and 149.5 cases from the impact of cadmium contained in food products.

8. The obtained results of the conducted hygienic assessment of contaminants presence in food products and the assessment of risk of the food products impact on population health are used to improve state sanitation and epidemiologic control in respect of business units and their 
production control over food products and food raw materials as well as for making managerial decisions.

\author{
FS - Federal Service; \\ FBIS - Federal Budget Institution of Science; \\ SHM - social-hygienic monitoring; \\ FIF - Federal Information Fund; \\ $\mathrm{AL}$ - Admissible level; \\ DDT - (dichloro-diphenyl-trichloroethane; \\ $\mathrm{HXCH}$ - hexachlorane; \\ CNS - central nervous system; \\ GIT - gastrointestinal tract; \\ CVS - cardiovascular system.
}

\title{
References
}

1. Gigienicheskie normativy (GN 1.2.2701-10) soderzhaniya pestitsidov v ob"ektakh okruzhayushchey sredy (perechen') [Hygienic Standards (GN 1.2.2701-10) of the content of pesticides in the environment (list)].

2. Doktrina prodovol'stvennoy bezopasnosti Rossiyskoy Federatsii. Utverzhdeno ukazom Prezidenta RF ot 30.01.2010 № 120 [Food Security Doctrine of the Russian Federation. The decree of the President of the Russian Federation of 30.01.2010 No. 120]. Avaible at: URL: http: //www.rg.ru/2010/02/03/prod-dok.html.

3. Edinye sanitarno-epidemiologicheskie i gigienicheskie trebovaniya $\mathrm{k}$ tovaram, podlezhashchim sanitarno-epidemiologicheskomu nadzoru (kontrolyu) [Uniform sanitary and epidemiological and hygienic requirements for goods subject to sanitary and epidemiological supervision (control)]. 2-e izdanie, ispravlennoe. Moscow, 2010: Federal'nyy tsentr gigieny i epidemiologii Rospotrebnadzora. 707 p.

4. Metodicheskie ukazaniya (MU 2.3.7.2519-09) Opredelenie ekspozitsii i otsenka riska vozdeystviya khimicheskikh kontaminantov pishchevykh produktov na naselenie [Methodical instructions (MU 2.3.7.2519-09). Determination of exposure and risk assessment of chemical contaminants of food on the population].

5. Metodicheskie ukazaniya (MU 2.3.7.2125-06) Sotsial'no-gigienicheskiy monitoring. Kontaminatsiya prodovol'stvennogo syr'ya i pishchevykh produktov khimicheskimi veshchestvami. Sbor, obrabotka i analiz pokazateley [Methodical instructions (MU 2.3.7.212506) Socio-hygienic monitoring. Contamination of food raw materials and food chemicals. Collection, processing and analysis of indicators].

6. Rukovodstvo po otsenke riska dlya zdorov'ya naseleniya pri vozdeystvii khimicheskikh veshchestv, zagryaznyayushchikh okruzhayushchuyu sredu R.2.1.10.1920-04 [Risk assessment guidance for health from exposure to chemicals polluting the environment R.2.1.10.1920 -04]. Moscow, 2004. 143 p. 